\title{
GOLDENEYE DUCK
}

\author{
D. WILBY, Heatherdown, Alta.
}

In 1947 a Pileated Woodpecker decided she would make a nest about five feet up in a dead poplar tree which stood about twenty feet from an unused house of ours. After making a hole about four inches in diameter and eighteen inches deep, she changed her. mind - probably too many people passing by..

Next year I was quite surprised to find that a Goldeneye Duck had adopted it as a home and laid nine eggs. Again in 1949 she laid ten eggs. When these eggs hatched I spent much of the day watching the nest hole from about fifty feet away. Some friends were with me for over an hour. All the time she sat on the edge of the hole and watched us. After tea we looked again but during that hour she somehow managed to get all the ducklings out.

In 1950 we put a ten-foot addition on the house and moved in. As the north end of the house was now only about ten feet from the tree, I expected she would leave, but no, she came there again. I thought we should become better friends, so whenever I went near the tree, I always said "Hello Ducky" several times. Then I -looked into the nest. She shuffled around a bit but stayed on it - so I put my hand in and she allowed me to stroke her head and back, then she gently pecked my hands. So this went on until 1953 - now five years she had nested there, but she always managed to get her babies out unseen. She had hatched all the eggs except one year, one egg did not hatch.

So this year, 1953, I kept a close watch. The ducklings all seemed to hatch during the night and in the morning when I went to see her the nest was full of little ducks. She allowed me to pick them up and have a good look at them. She kept them in all day to dry off and gain strength to make the five feet down to the ground. So I watched until she perched on the edge of the nest. "Now", I thought "I will see how she gets them out". I went into the house as there was a window facing the nest hole - with a curtain on it. I hid behind the curtain with just my head out, so I could see plainly. It wasn't long till she flew down to the ground and started off through the vegetation, and I lost sight of her. After a while she came back and went into the nest. She did this two or three times until she had made a path through the weeds, etc. Now she took a position about four or five feet from the tree, facing the hole, and talked to them in duck language, explaining that all was ready for them to come out - and out they came. They scrambled up the side of the hole, perched on the edge a moment, then jumped towards their mother and cuddled down beside her, one by one. Then she went through the path she had made - all ten little ducklings waddling after her. She went so quickly that I coudn't see how they could keep up to her. Away they went, across the garden to a pile of straw that I had used for winter mulch. Somehow or other they all managed to scramble over it and into the bush It was about half a mile by the route she took in order to reach the creek. If she had gone straight out from the tree she could have halved the distance, all of which proves to me that ducks' ways are not our ways, believing as we do that a straight line is the shortest distance to a given point.

So that is the end of my story. I never saw them again. I expect they worked their way the six or eight miles down the creek to a lake. Next year, if here, I will try to follow them to see if they all arrive safely.

How apt are we to dismiss the winter landscape as a drab monotone of black and white, yet by the discerning eye, how much color can be found. A low spot with a large patch of slender red willows, rich, dark crimson below, shading to bright flame-color at the tips of the twigs, is a delight to the eye, while a single tree-like stem of the wild rose, heavily laden with scarlet hips, makes a sharp accent against the snow. 